\title{
Nucleation of microcracks and their propagation in gravity-cast Al-Si and Al-Li alloys
}

\author{
Zarodkowanie mikropęknięć oraz ich propagacja \\ w grawitacyjnych odlewach ze stopów Al-Si oraz Al-Li
}

\begin{abstract}
This article discusses the nucleation and propagation of microcracks in gravity-cast aluminum-silicon and aluminum-lit alloys. Microstructural observations were made on both an optical microscope and a scanning electron microscope. In addition, hardness measurements were made using the Vickers indenter and strength tests - a static compression test. Experiments have allowed us to determine the very important differences in both the nucleation and propagation of microcracks emerging after crossing the yield point between gravity-cast aluminum-silicon aluminum alloys.
\end{abstract}

Keywords: gravity-cast aluminum alloys-silicon, gravity-cast aluminum alloys-lit; nucleation of microcracks, propagation of microcracks

\section{Streszczenie}

W niniejszym artykule omówiono sposób zarodkowania oraz propagacji mikropęknięć w grawitacyjnie odlewanych stopach typu aluminium-krzem oraz aluminium-lit. Obserwacje mikrostrukturalne prowadzono zarówno na mikroskopie optycznym, jak i na skaningowym mikroskopie elektronowym. Ponadto wykonano pomiary twardości, korzystając z wgłębnika Vickersa, oraz badania wytrzymałościowe - statyczną próbę ściskania. Eksperymenty pozwoliły wyznaczyć bardzo istotne różnice zarówno w zarodkowaniu, jak i propagacji mikropęknięć pojawiających się po przekroczeniu granicy plastyczności między grawitacyjnie odlewanym stopami aluminium-krzem a aluminium-lit.

Słowa kluczowe: grawitacyjnie odlewane stopy aluminium-krzem, grawitacyjnie odlewane stopy aluminium-lit, zarodkowanie mikropęknięć, propagacja mikropęknięć

\section{Introduction}

Nowadays, changes in the automotive, aerospace, and military industries are happening very quickly. More-suitable materials are still being sought with better mechanical and

Justyna Grzegorek M.Sc. Eng., Anna Tarasek Ph.D. Eng., Łukasz Maj M.Sc. Eng.: Institute of Metallurgy and Materials Science of Polish Academy of Science, Krakow; Barbara Olszowska-Sobieraj Ph.D. Eng.: AGH University of Science and Technology, Faculty of Foundry Engineering, Krakow, Poland; stolarska.j@imim.pl 
plastic properties and high corrosion and fatigue resistance as well as being easily treatable. Steel is no longer dominant, but alloys of aluminum and titanium are [1-3]. When designing new material, the so-called structural parameter (i.e., the ratio of a material's strength to its density) sometimes allows for a significant reduction in the weight of the finished component and, as a result, reduces operating costs via lower fuel consumption, for example. Aluminum alloys (e.g., with the addition silicon or lithium) meet these requirements. The desired properties of the material can be obtained by the appropriate selection of chemical composition and appropriate crystallization parameters (gravity and pressure casting) [2].

In addition to the design advantages, a material's resistance to microcrack formation is also important. The cracking of a material, which ultimately causes its destruction, begins at places with the highest stress concentration (i.e., in the proximity of all microstructure defects: grain boundaries, non-metallic inclusions, or hard phases). It has already been reported for Al-Si alloys that the initiation of microcracks occurs in the hard eutectic silicon particles $[4,5]$ but also at the boundaries between the matrix and the precipitates. An increase in external loads results in the accumulation of microcracks that combine and create a macrocrack that leads to the material's destruction.

It is well known that the chemical composition of the alloy determines the initial properties of the material. The new generation of aluminum-lithium alloys may be considered a good example. A small addition of lithium (even of $~ 1 \mathrm{wt} . \%$ ) causes a 3\% decrease in the density of an Al-based alloy (as a result, the weight of the final construction element is significantly reduced) with a simultaneous increase in the modulus of elasticity (Young's modulus); i.e., up to 6\%. This alloy makes an excellent material for aircraft or rocket elements. Moreover, a Li addition greater than $2 \mathrm{wt} . \%$ causes an anisotropy of a material's properties, decreases its plasticity and resistance to cracking, and increases its thermal instability [6]. However, the cracking behavior of gravity-cast Al-Li alloys has not been investigated as of yet.

Therefore, the aim of the present work was to analyze microcrack formation in gravity-cast Al-Li alloys through microstructure investigations of "as-cast" material (after a static compression test) and to compare the obtained results with Al-Si material. The microstructure observations were conducted by means of optical and scanning electron microscopy. These observations were backed by static compression and hardness tests.

\section{Materials and methods}

Two hypoeutectic alloys were selected for the study:

- aluminum with silicon (6.2\% Si; 0.39\% Mg; 0.02\% Mn; 0.04\% Fe; 0.01\% Ti),

- aluminum with lithium ( $2 \% \mathrm{Li} ; 0.2 \% \mathrm{Si} ; 0.39 \% \mathrm{Mg} .0 .01 \% \mathrm{Mn} ; 0.03 \% \mathrm{Fe} ; 0.01 \% \mathrm{Ti}$ ).

The above-listed alloys were gravity-cast where the casting parameters were optimized in order to obtain a wall thickness of $40 \mathrm{~mm}$. 
The metallographic sections have been prepared through the grinding of each alloy surface with the use of abrasive papers of up to 7000 grit and polishing it with a $1-\mu \mathrm{m}$ diamond suspension.

The microstructure observations of the samples were carried out with the use of a Leica metallographic optical microscope and Philips XL30 scanning electron microscope (SEM) in backscattered electron mode (BSE).

The mechanical strength evaluation through static compression tests was carried out in order to establish the locations of the appearance of microcracks in the analyzed gravity-cast alloys. They were performed using an INSTRON 6025 dedicated stand upgraded by Zwick/Roell. The hardness measurements of the Al-Si and Al-Li alloys were also performed using a Zwick/Roell ZHU250 universal hardness tester using the Vickers indenter.

\section{Results and discussion}

The microstructure images of the investigated initial ("as-cast") Al-Si and Al-Li alloys are presented in Figure 1 and Figure 2, respectively. It may be noticed that the microstructure of the initial material does not present any microcracks.

a)

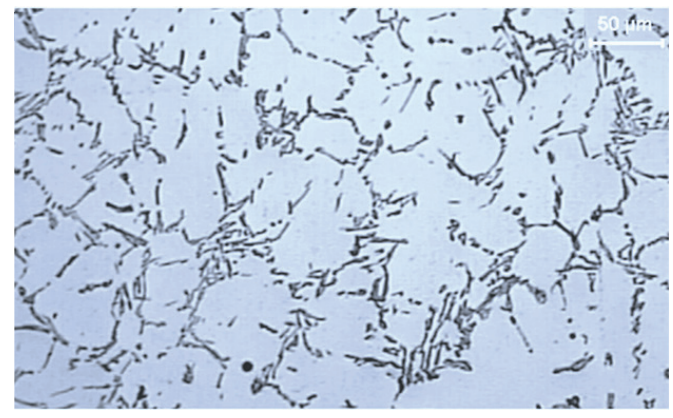

b)

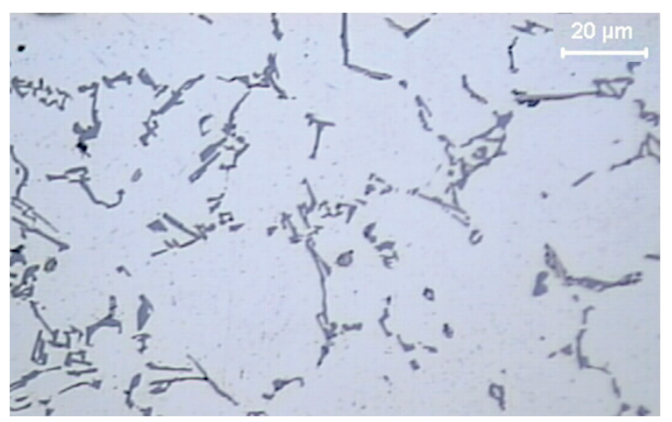

Fig. 1. Optical microscopy images of microstructure of gravity-cast Al-Si alloy acquired at different magnifications: a) 200x; b) 500c; metallographic section was not etched 
a)

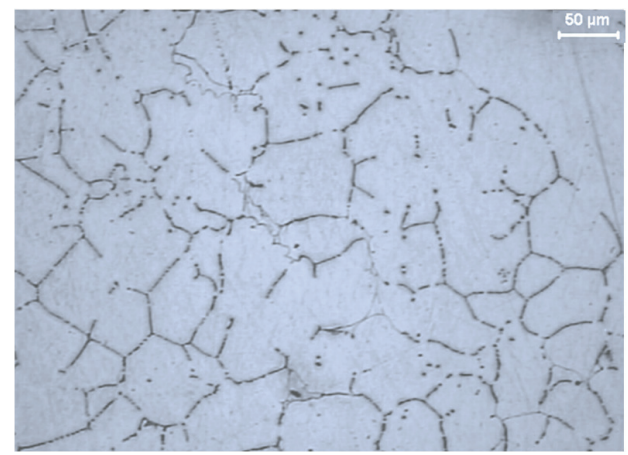

b)

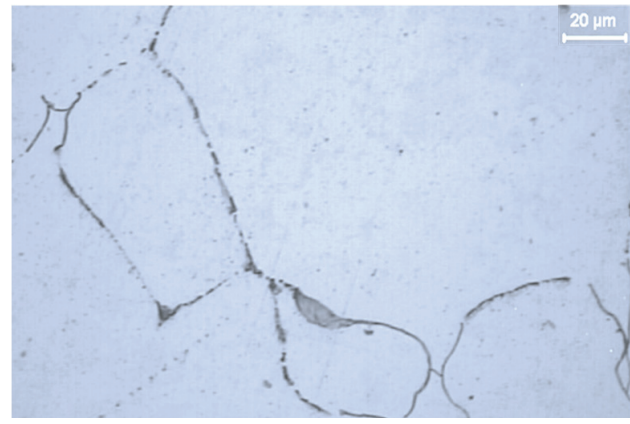

Fig. 2. Optical microscopy images of microstructure of gravity-cast Al-Li alloy acquired at different magnifications: a) 200x; b) 500x; etched metallographic section: $10 \% \mathrm{NaOH}$

The performed hardness measurements of the "as-cast" Al-Li and Al-Si alloys showed that the average hardness for the former is $~ 40 \mathrm{HV} 5$, while the latter is much harder (i.e., 90 HV5). The average results are summarized in Figure 3.

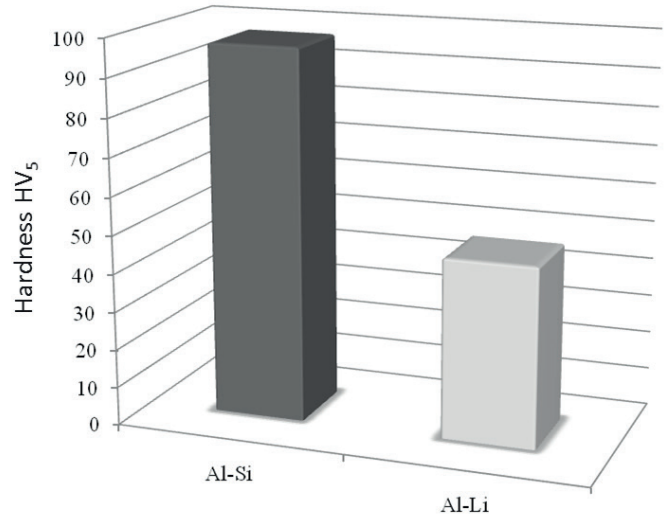

Fig. 3. Results of hardness tests of "as-cast" Al-Si and Al-Li alloys 
In the second stage of the work (after characterization of the initial materials), a static test of the material under study was performed. Results from the above sample are shown in Figures 4, 5 and 6.
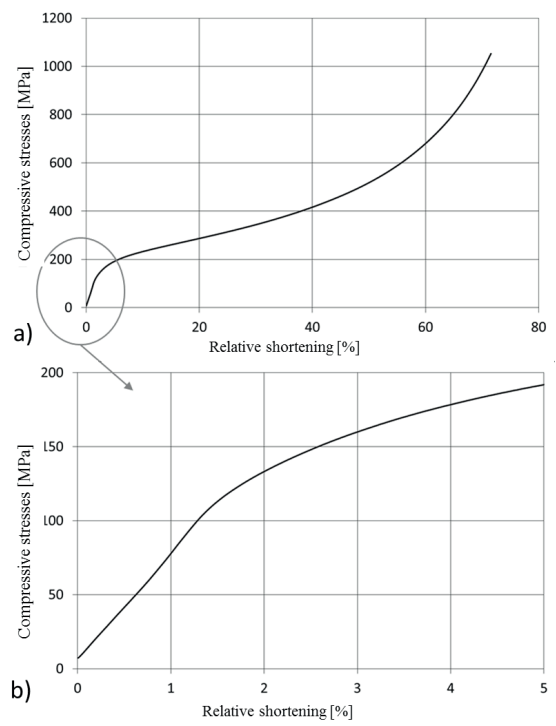

Fig. 4. Results of static compression test for gravity-cast Al-Si alloy
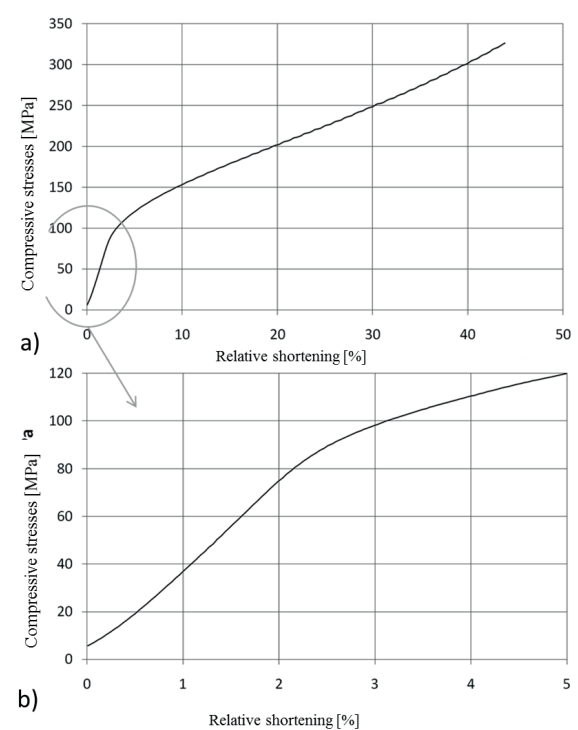

Fig. 5. Results of static compression test for gravity-cast Al-Li alloy 


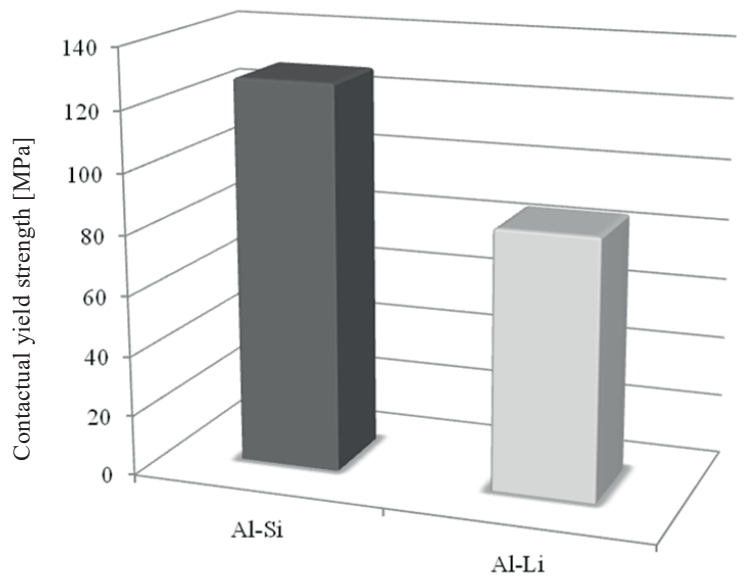

Fig. 6. Average yield point determined by static compression test for Al-Si and Al-Li alloys tested
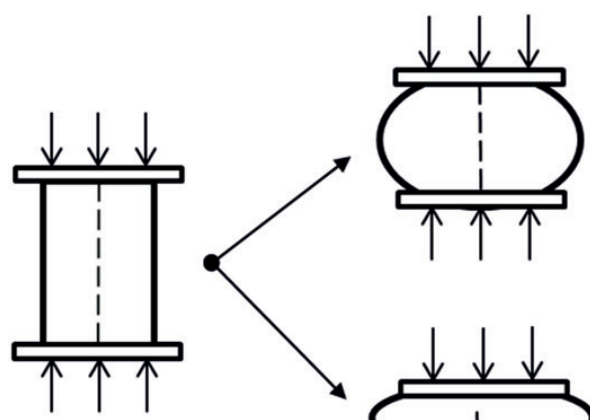

Al-Si alloy

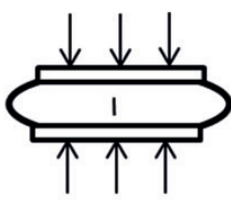

Al-Li alloy

Fig. 7. Deformation state of samples after static compression of Al-Si and Al-Li alloys

The metallographic sections were also made for all samples after static compression tests (Fig. 7) in the same way as in the case of the "as-cast" alloys, and their microstructures were investigated in order to observe and describe the formation of brand new microcracks as well as any propagation of those present in the initial alloys. It is worth noting that, after exceeding the yield point limit in a static compression test, the microstructure observations of the Al-Si alloys (using the optical microscope) revealed the presence of microcracks mainly in the precipitated eutectic silicon phases distributed at the grain boundaries of solid solution $\alpha$ (Fig. 8). 


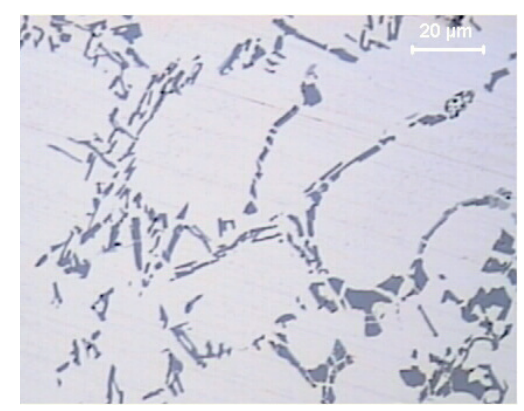

Fig. 8. Exemplary Al-Si alloy microstructure after static compression test; not digested metallographic

The microstructure observations of the Al-Si alloys after the static compression test carried out using the SEM in backscattered electron mode allowed us to evaluate the quality and quantity of the microcracks that appear in the needle-shaped eutectic silicon phases. It has to be noted that none of the analyzed samples exhibited the propagation of the above-mentioned microcracks nucleated in the eutectic silicon phases and their propagation in the $\alpha$ solid solution (Fig. 9).

a)

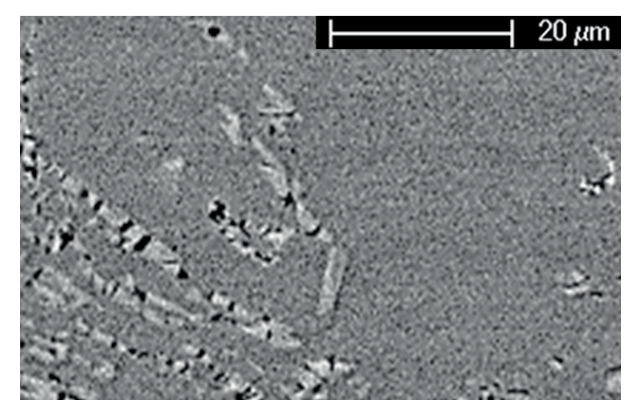

b)

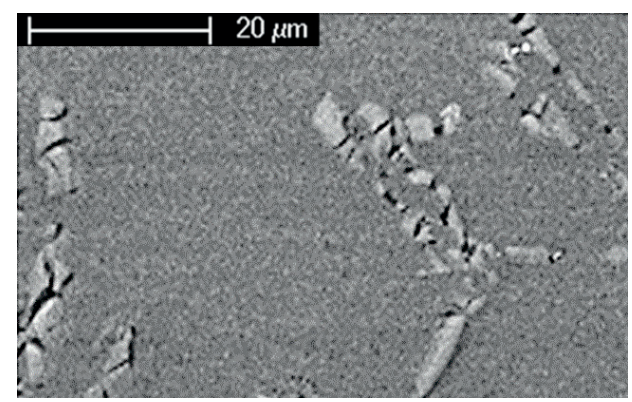

c)

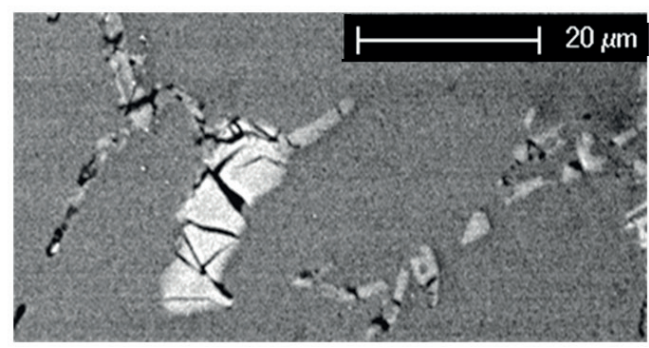

Fig. 9. BSE-SEM images of microstructure of Al-Si alloy after static compression test (metallographic section was not etched) 
On the other hand, the microcracks in the case of the Al-Li alloy were not identified. A very high degree of deformation of all grains of the solid solution was observed, and it was only after significantly exceeding the yield point when the cracks could be observed simultaneously at the boundaries being parallel to the deformed packages (Fig. 10).

a)

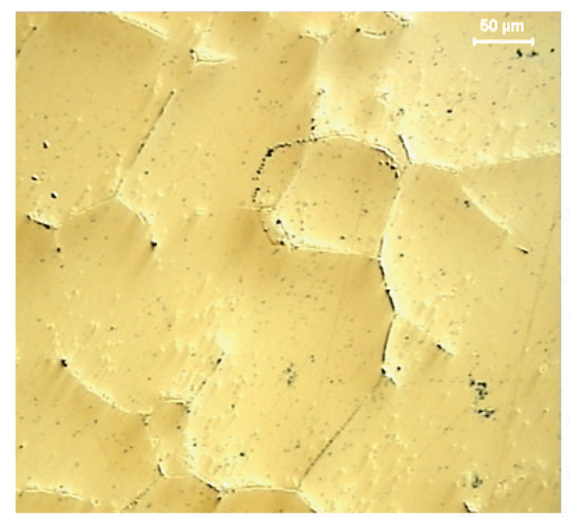

b)

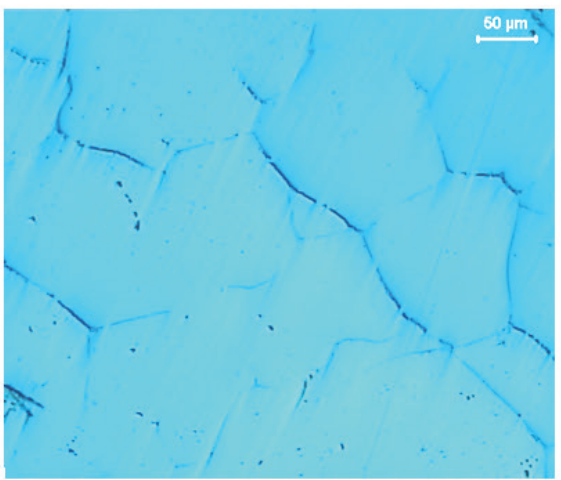

c)

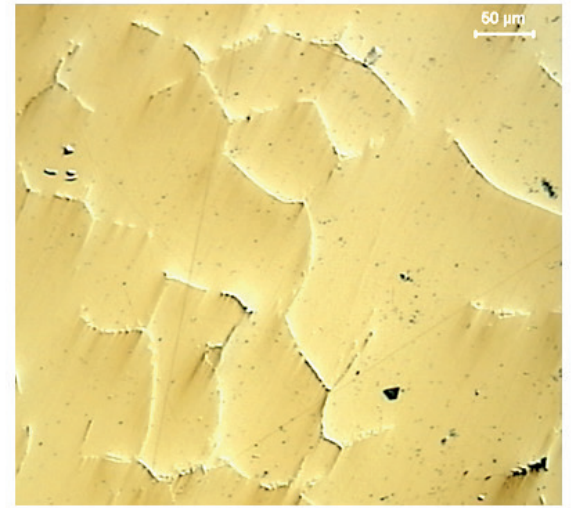

Fig. 10. Example Al-Li alloy microstructure after static compression test (not etched metallographic) 
Microstructural deformation resulted in the formation of packages, and the microcracks started to appear only under heavy loads; first parallel to the band structure of the sample and then perpendicularly (Fig. 11).

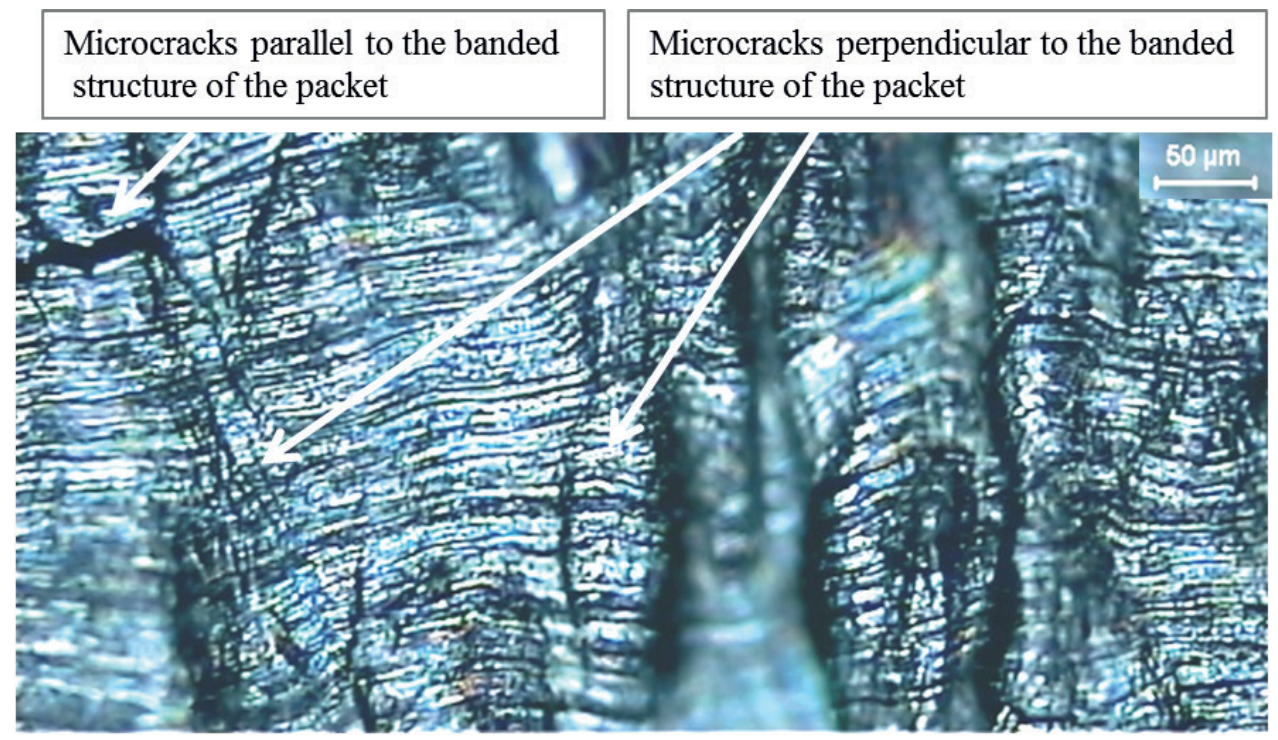

Fig. 11. Exemplary side wall microstructure after static compression test

\section{Conclusions}

The phenomena associated with nucleation (after exceeding the yield point), the microcracks and their propagation in the microstructure of gravity-cast hypoeutectic aluminum-silicon and aluminum-lithium alloys are completely different:

- In aluminum-silicon alloys (gravity-cast), the nucleation of microcracks is located only in the needle-shaped eutectic silicon precipitates. All initiated cracks propagate in brittle silicon, parallel to each other but perpendicular to the compressive forces. Even with a significant yield point cross-over, the propagation of these microcracks by the $\alpha$-grains was not observed.

- In aluminum-lithium alloys (also gravity-cast), the nucleation of the first microcracks was observed only at the contact point of three grains of the solid solution $\alpha$. At the same time, packages of deformed grains of solid solution $\alpha$ began to appear, and only for very significant exceeding of the yield point, microcracks appeared; both parallel to the packages formed by the deformed solid solution $\alpha$ and perpendicularly at the boundaries of the individual packages. 


\section{Acknowledgement}

Microstructure investigation and mechanical measurements were performed in the Accredited Testing Laboratories at the Institute of Metallurgy and Materials Science, PAS.

\section{References}

[1] Górny Z., Sobczak J.: Nowoczesne tworzywa odlewnicze na bazie metali nieżelaznych. ZA-PIS, Kraków 2005

[2] Dobrzański L.A.: Materiały inżynierskie i projektowanie materiałów. Podstawy nauki o materiałach i metaloznawstwo. Wydawnictwa Naukowo-Techniczne, Warszawa 2006

[3] Bielawski R., Rządkowski W., Augustyn S., Pyrzanowski P.: Nowoczesne materiały stosowane w konstrukcjach lotniczych - wybrane problemy oraz kierunki rozwoju. Zeszyty Naukowe Politechniki Rzeszowskiej 291, Mechanika 87, RUTMech, t. XXXII, z. 87 (3/15), lipiec-wrzesień 2015, 203-216

[4] Tarasek A., Olszowska-Sobieraj B., Stolarska J., Uliasz P.: The influence of the technology of microstructure formation and properties of AIMgSi alloys on the microcracks under load of static compression. Key Engineering Materials, 682 (2016), 99-106

[5] Grzegorek J., Tarasek A., Olszowska-Sobieraj B., Lewicki P.: Ocena zmian parametrów stereologicznych faz eutektycznych w stopie AISiMg po utwardzaniu wydzieleniowym. Wydawnictwo Naukowe Akapit, Kraków 2016

[6] Eswara Prasad N., Amol Gokhale, Wanhill R.J.H. (eds.): Aluminium-Lithium Alloys. Processing, Properties and Application. Elsevier, 2014 